\title{
Bio-historical diversity, sustainability and collaboration in the Xingu
}

\section{Michael Heckenberger}

\section{(2) OpenEdition \\ 1 Journals}

Electronic version

URL: http://journals.openedition.org/aa/1250

DOI: 10.4000/aa.1250

ISSN: 2357-738X

\section{Publisher}

Programa de Pós-Graduação em Antropologia Social (UnB)

\section{Printed version}

Date of publication: 1 December 2014

Number of pages: 69-96

ISSN: 0102-4302

\section{Electronic reference}

Michael Heckenberger, "Bio-historical diversity, sustainability and collaboration in the Xingu", Anuário Antropológico [Online], v.39 n.2 | 2014, Online since 01 August 2017, connection on 28 April 2021. URL: http://journals.openedition.org/aa/1250 ; DOl: https://doi.org/10.4000/aa.1250

\section{(c) (i) (9)}

Anuário Antropológico is licensed under a Creative Commons Atribuição-Uso Não-Comercial-Proibição de realização de Obras Derivadas 4.0 International. 


\title{
Bio-historical diversity, sustainability and collaboration in the Xingu
}

\author{
Michael Heckenberger \\ University of Florida
}

\section{Introduction}

The Amazon region is an icon for global ecological well-being. It is the home to remarkable biodiversity and is an important climatic regulator, providing climate stabilization, carbon sequestration and protecting hydrological cycles, among other ecosystem services. The region is critical to economic security and growth, particularly associated with Brazil's meteoric economic rise in the $21^{\text {st }}$ century. Amazonia is also one of the most culturally and linguistically diverse regions of the planet and the plight of its traditional indigenous peoples in the face of rapid development are widely recognized as an urgent social concern. This bio-historical diversity is widely seen to include diverse pre-Columbian complex societies with developed sophisticated systems of land-use and management and engineered landscapes, as well as the historical legacy of colonialism and globalization (Balée, 2010; Balée \& Erickson, 2006; Heckenberger \& Neves, 2009; Rostain, 2012; Schaan, 2011). Not surprisingly, the fate of the Amazon forest - the "lungs of the world" - is highly contentious, reflecting often conflicting perceptions and interests of conservation and development, heritage and human rights and larger scale drivers of socio-ecological and climate change (Alcorn \& Zarzycki, 2005; Chapin, 2004; Hecht, 2013; Schmink, 2011; Schwartzman et al., 2013; Schwartzman \& Zimmerman, 2005).

In the Brazilian Amazon, indigenous areas currently preserve the largest tracts of continuous standing forests and are the most important barrier to deforestation, particularly in the southern Amazon's "arc of deforestation" (Nepstad et al., 2006). At 29 million hectares, the corridor is the world's largest contiguous tract of tropical forest still under indigenous and traditional resource management, although acutely threatened by development outside the corridor (Figure 2A and 2B). The Xingu corridor preserves substantial pre-Columbian socio-historical variation in the Xingu corridor (Schwartzman et al., 2013). This included large pre-Columbian populations with semi-intensive systems of agricultural and wetland land-use, which dramatically changed land-cover over the long-term, particularly ca. 500-1000 years ago (Heckenberger et al., 2003, 2008). This included radical changes following European contact, ca. 
1550-1650, including widespread forest fallowing that resulted in the closed forest conditions that prevail across the area today (Dull et al., 2010).

The Upper Xingu is a "hotspot" of both biodiversity and cultural and historical diversity, including the legacy of large settled Amerindian communities in substantially modified and, in several cases, carefully engineered landscapes. There is a significant disconnect, however, between historical and ecological analyses, including incorporation of indigenous voices and local participants, despite widespread use of the term "socio-ecological" in recent literature (Brondizio et al., 2009). The even more critical point is that these voices must be incorporated into global discourses, and the institutional structure of governance in broader society, not merely as evolutionists have wanted them to be: primitives. To avoid the "willful ignorance" of this imperative in contemporary research, by stranding indigenous groups in a state of "suspended animation," the primitive (Ramos, 1998). They are both stakeholders and partners in contemporary struggles.

In Amazonia, and in many parts of the Global South and, particularly, Native America, this depends on archaeology, as much as any other single discipline, to bridge social, historical and ecological perspectives. To address complex issues of economic, social and environmental sustainability in the Amazon, collaborative research networks are needed to produce shared interdisciplinary and multi-scalar understandings of coupled ecological and socio-historical systems. Within these networks, archaeology takes on an expanded role, far greater than many other world areas, to understanding long-term human-natural systems and as a means to promote greater integration between scientific research and broader society needed within the context of sustainability. This is also the unique contribution of the Amazon to archaeology and world history, as the last area of the world to be fully embraced as a global macro-region no less eventful or driven by large-scale forces, including colonialism, native empires, social networks, including large inter-connected polities and anthropogenic transformations, and the knowledge production industry itself.

Specifically, integrated Xingu basin-wide research coordination networks aimed to document, preserve and monitor cultural heritage and biodiversity resources are a widely anticipated direction for all future research in the region. Research at the meso-scale of regions and large protected areas are needed to articulate local contexts to larger areas, in this case non-indigenous areas, and larger-scale drivers, such as climate and economic development, such as agriculture, hydro-dams and urbanism. Such basin-wide or similar meso-scale regional studies in Amazonia depend on research strategies that articulate indigenous 
groups, NGOs and scientists and foster common research agendas for understanding future changes and implementing local actions for coordinated sustainable development. Collaborative research provides a solid foundation for the study of dynamic and multi-scalar processes of landscape and cultural change over the past millennium among indigenous Amerindian peoples and other traditional populations in the Xingu basin (e.g. rubber-tappers and riverine-forest extractive communities).

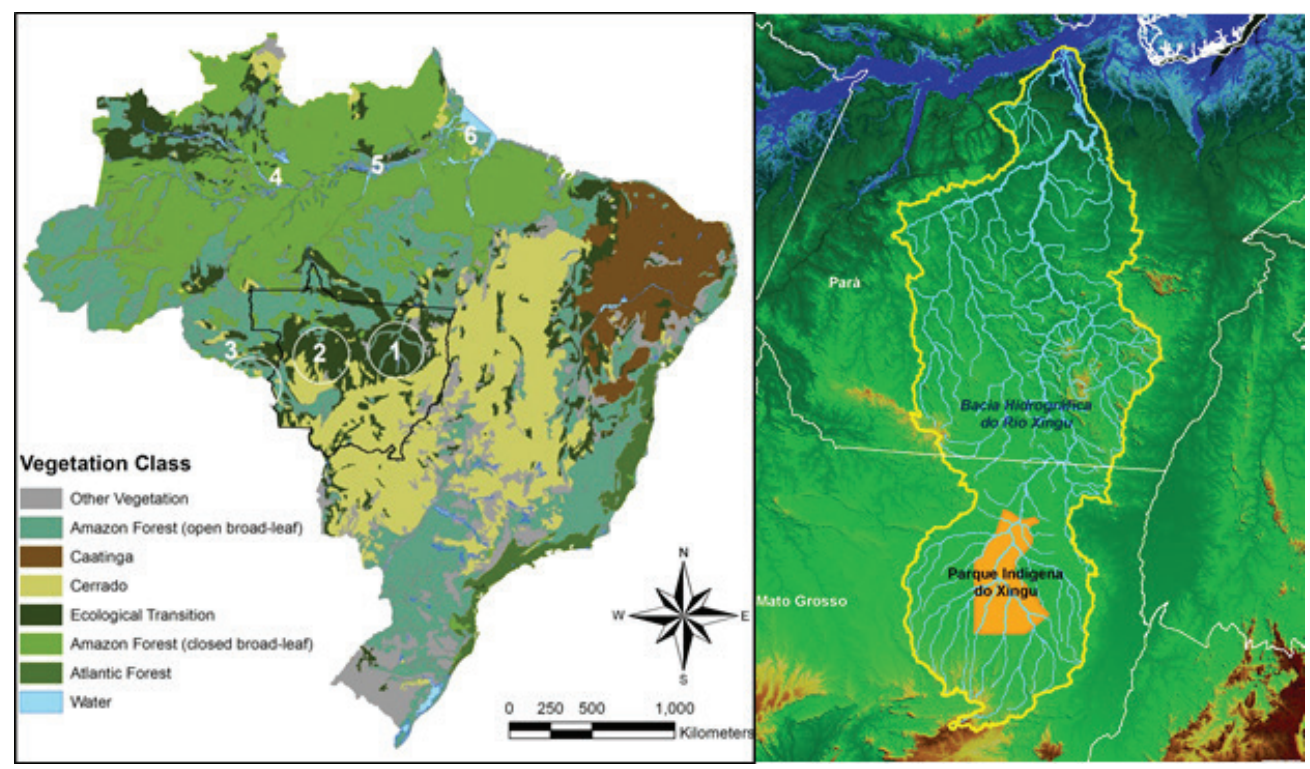

Figure 1. A (left). Map of Brazil showing major vegetative classes and six areas of Pre-Columbian complex societies (Upper Xingu 1 and lower Xingu between 5 and 6; from Heckenberger et al. 2008); B. Xingu drainage basin (source: ISA).

\section{Bio-historical diversity, landscapes \& sustainability}

Today, regional specialists agree that humans and environments in Amazonia act recursively, rather than directionally (i.e., one simply causing change in the other). As Cleary (2001:65) notes: "interpretations of the Amazon that stress environmental constraints on human agency or portray it as largely virginal or unsettled prior to the modern period are at best an oversimplification". Models of socio-ecological change in Amazonia must address this variation in Amerindian systems, ranging from small-scale, low impact systems to fairly large-scale systems that heavily influenced local landscapes in the past, creating unique "islands" or mosaics of bio-historical diversity (Balée, 2010; Balée \& Erickson, 2006; Denevan, 2001; Erickson \& Balée, 2006; Heckenberger, 2010; Posey \& Balée, 1989). Recent findings are part of a growing realization that 
pre-modern peoples in many parts of the world were capable of having a major impact on plant and animal communities, hydrology, and even climate (Mason, 2004; Ruddiman, 2003, 2013; Willis et al., 2004, 2007).

Two areas, in particular, show substantial archaeological evidence of major human alterations of the forested landscapes in prehistoric times, including forest cover, soils, and wetland management (Figure 1A): the floodplains (várzea) of the lower and middle Amazon, including the Lower Xingu (Neves \& Petersen, 2006; Schaan, 2011; Woods et al., 2009) and the southern Amazon transitional forests, including the Upper Xingu headwater basin (Erickson \& Balée, 2006; Heckenberger, 2005; Heckenberger et al., 2003, 2008; Schaan, 2011). In general terms, pre-Columbian forest alteration and landscape engineering was most clearly associated with the emergence of powerful regional polities, ca. 1500-400 BP, followed by a period of forest fallowing after European colonialism (Bush et al., 2008; Clement, 1999; Dull et al., 2010).

Recent impact studies related to major dams and urban development in the Lower Xingu, likewise confirm large, dense regional populations were present in pre-Columbian times, as recognized in the lower reaches of other southern tributaries and along the Amazon (várzea). Cultural and historical variation and change over the past 200-300 years and sporadic archaeological evidence indicate dense populations and significant landscape modification, including anthropogenic soils were widespread across the Xingu basin, although highly variable (Balée, 1989; Hecht, 2003; Posey, 2002; Schwartzman et al., 2013).The forested environments also preserve an unparalleled record of the post-contact (post-AD 1500) "fallowing" of much of the landscape associated with demographic collapse of Amerindian populations, between the $16^{\text {th }}$ and $20^{\text {th }}$ centuries (Heckenberger, 2005, 2010; Heckenberger et al., 2003, 2008).

Nonetheless, detailed interdisciplinary studies of anthropogenic landscapes in Amazonia are rare and pre-Columbian and historic complex societies are poorly understood in terms of scale, land-use, and impact on forest ecologies. In the Xingu River basin, archaeological research is lacking for most of the basin, but in-depth research has been conducted in the extreme upper reaches of the Xingu River (Figure 1B). This provides a clear example of complex socio-ecological systems among pre-Columbian and historic Amerindian social formations, as revealed through participatory GPS mapping, archaeological investigations, remote sensing and GIS (Figure 2C) due to the anthropogenic footprint of ancient complex societies and contiguous protected forest (Heckenberger et al., 2007; Willis et al., 2004). Densely settled agricultural populations did not denude the landscape of trees, as commonly practiced in modern developmental 
practices, but instead created patchy (spatially and seasonally) mosaic patterns of land-use. Like today, these would have incorporated diverse forest and wetland management strategies, including sequential multi-cropping in long-term rotational cycles of agriculture and arboriculture, large-scale wetland management, and patchy land-use and forest "connectivity" through habitat corridors.

The term "cultural landscape," as used by UNESCO to define the "combined works" of nature and humankind, aptly characterizes areas like the Xingu basin (Schwartzman et al., 2013):

Protection of cultural landscapes can contribute to modern techniques of sustainable land-use and can maintain or enhance natural values in the landscape. The continued existence of traditional forms of land-use supports biological diversity in many regions of the world. The protection of traditional cultural landscapes is therefore helpful in maintaining biological diversity (UNESCO website).

As Erickson (2006:237) sums up, the idea of cultural landscapes suggests that "understanding the environment as an indigenous creation [a palimpsest and a work in progress] is much more useful and accurate than the common practice of describing humans as simply "adapting to," "impacting," "transforming," "altering," or "socializing" a static background."

In Amazonia, the "archaeology of landscape" is tied less to explicitly phenomenological perspectives (Ingold, 2001, 2013; Hodder, 2012), but instead aim to develop concrete linkages between cultural and historical factors, on the one hand, as studied by anthropologists, and environment and climate, on the other, to help understand and manage significant change and devise alternative strategies for development based on past semi-intensive land-use (Schwartzman et al., 2010; Redford \& Sanderson, 2000). Such intensive indigenous systems are not only critical to understanding the composition of the Amazon region, but provide a middle ground between potentially harmful extensive (slash-and-burn) and entirely destructive clear-cutting development (Laurence et al., 2001). Indigenous resource management strategies, in particular, may hold important clues to sustainable regional development and climate change mitigation and adaptation over the long term (Ashby, 2003; Vernooy \& MacDougall, 2003). 
A.

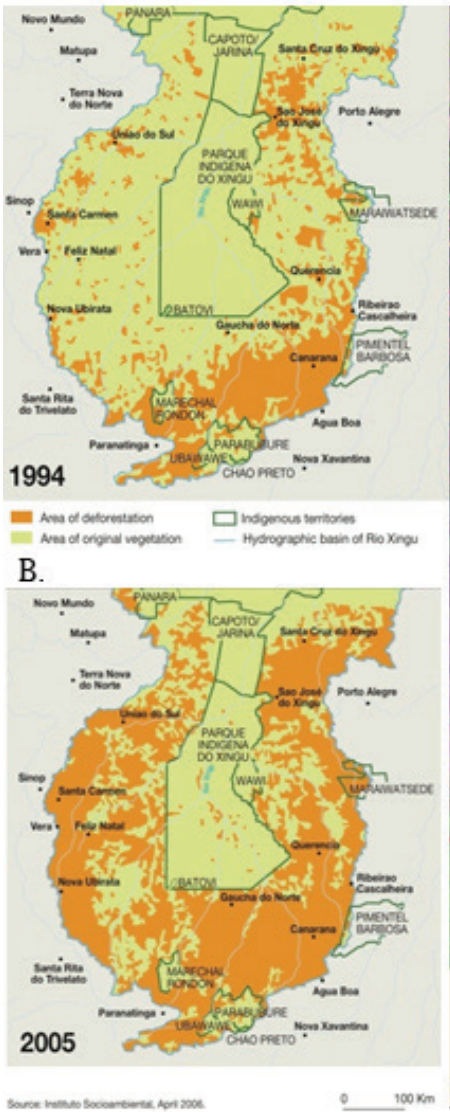

C.

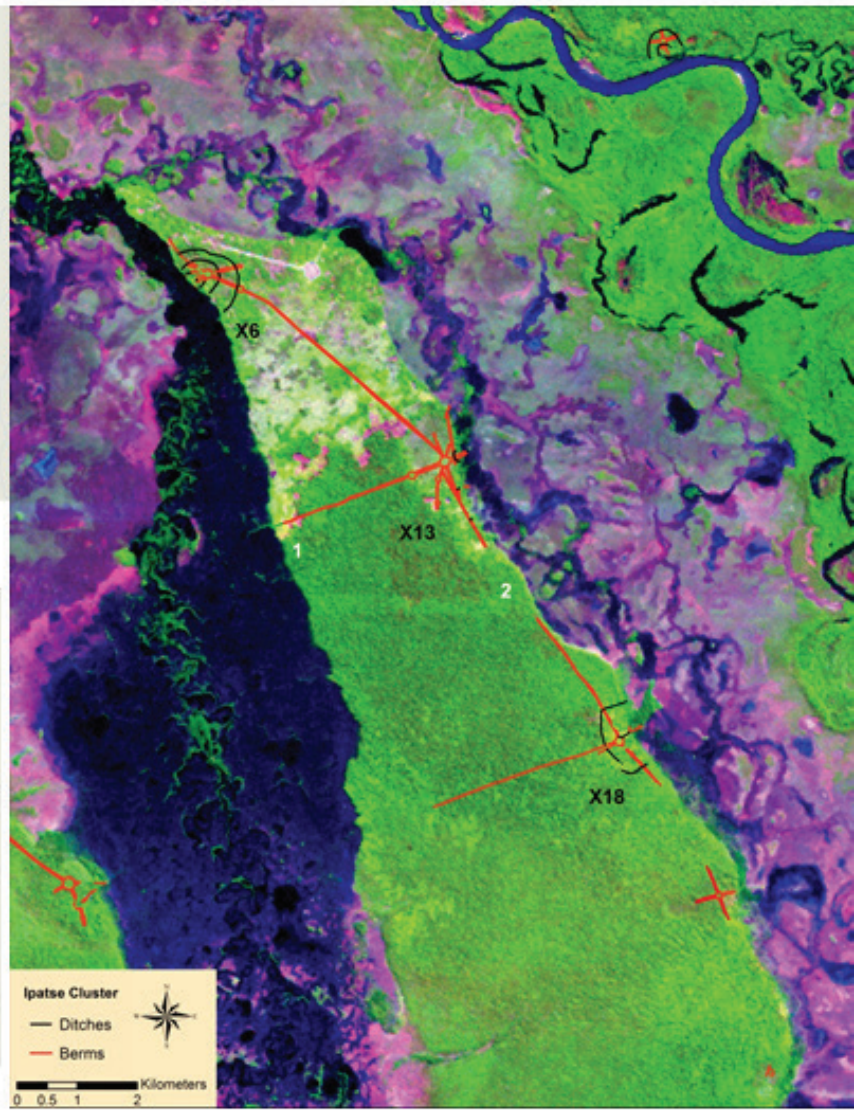

Figure 2. A and B. Deforestation in the Upper Xingu Basin (ISA 2010); C. Map showing GPS mapped Pre-Columbian roads (red line) and defensive walls (black line) associated with major occupation sites (20-50 hectares) in forest areas.

In other words, suddenly some of the best answers to the vexing question of how to "Save the Amazon," in terms of conservation and development, are provided by its indigenous peoples, who constructed and managed forest and wetland technologies that worked with the natural environment, not against it.

Sustainability science provides a conceptual framework for addressing the pluralistic nature of contemporary research, notably by focusing on: (a) scalar properties of natural-human systems and interactions within and between scales; (b) multi-disciplinary research strategies, including change in coupled bio-physical and socio-historical systems; and, (c) multiple domains (e.g., ecological, economic, and socio-cultural factors), which are multi-vocal and open to diverse interpretations, including those of local indigenous and other rural peoples (Martens, 2006). The viewpoint of sustainability science promotes the 
co-production of knowledge and a process of "learning through doing and doing through learning," which stimulates both interdisciplinary and intercultural interactions as an active part of research design (Gezon \& Paulson, 2005). In Amazonia, three areas of contemporary debate on the socio-political, socio-economic and the socio-ecological dimensions of sustainability are critical: a) bio-historical diversity and anthropogenic landscapes, b) resilience and contemporary sustainability studies, and c) collaboration between scientists, NGOs, and indigenous peoples and other stakeholders.

Sustainability studies are often tied to the concept of ecological resilience, defined as "the amount of disturbance that an ecosystem could withstand without changing self-organized processes and structures” (Gunderson, 2000:14). It has been a keystone concept in interdisciplinary research on coupled human-natural systems and broader questions of sustainability for over a decade (Berkes \& Folke, 1998; Folke, 2006; Gunderson \& Holling, 2002). It is widely used in models of historical change and "plasticity" of tropical forest ecosystems, the lack of historical time depth often hinders robust reconstructions or modeling. A decade ago, Fisher and Feinman (2005:62) noted, paraphrasing an editorial in Science (Kennedy, 2004:1565), that: "time depth for both human and environmental records is a prerequisite if we are to assess and explain correlations between human-environmental interactions and ultimately determine whether apparent trends are meaningful, directional, or neither (e.g., Crowley 2000).”

Archaeology provides a unique long-term perspective on adaptive cycles (Redman \& Kinzig, 2003:14) and, as Stahl (1996:117; see also 1995) points out that studies of Holocene environmental and climate change "rely on the techniques and methodologies of archaeology for generating inferences about a deep time that existed beyond human memory and before the advent of written documents." Nonetheless, Redman's (2005:71) observation a decade ago that there are "only a few integrative ecological studies of human land use cover time scales longer than a century," citing the Upper Xingu (Heckenberger et al., 2003) as one of a handful worldwide, still equally prevails today. Socio-ecological resilience is often central to contemporary research on global climate change, biodiversity loss, ecosystem restoration, and socio-economic development but rarely addresses long-term socio-historical variation and cultural heritage of living peoples, notably the Xingu basin (Brondizio et al., 2009).

In Amazonia, generally, resilience rarely attends to anthropogenic landscapes, despite widespread agreement among historical that non-altered forest dominate many areas and their ability to withstand or recover from shock, in this case from climate fluctuation and land cover change, which differ dramatically 
from minimally influenced and non-anthropogenic settings (Balée, 2013; Hecht et al., 2013; Schwartzman et al., 2103). Thus, ecological resilience and sustainability should be placed in the context of longer-term histories, which include secondary or altered - anthropogenic - forest landscapes, rather than primary forest settings (forests that are not directly influenced by humans in the past). While these areas likely constitute $>10 \%$ of the region and have greater potential for human use, as reflected in past land-use practices, most remain poorly known (Heckenberger \& Neves, 2009). Landscape transformation in Amazonia rarely attains the degree that ecologists would characterize as primary succession, but large-scale transformations were common across the southern Amazon (Heckenberger, 2010, 2013).

The lack of attention to long-term human influences likewise fails to address fundamental questions posed by political ecology, particularly the implications of complex socio-ecological systems and cultural heritage in the contested frontiers of Amazonia (Hecht, 2013; Schmink \& Woods, 2013). This demands that humans are treated as active agents and research partners in the creation of common frameworks for problem-oriented research that address both cultural and non-cultural factors, including indigenous rights. Contemporary approaches place not only in the context of ecological resilience but also with respect to social and ethical questions in the broader context of sustainability and indigenous peoples (Davidson et al., 2012; Gezon \& Paulson, 2005; Pretty et al., 2009). The goal, however, intends also to develop mechanisms for sharing and articulation across broader geographic regions and domains of knowledge, enabling linkages between disciplines and scales based on research conducted in collaboration with diverse cultural stakeholders, notably indigenous peoples.

\section{The Upper Xingu}

The cultural landscapes of the Xingu watershed preserve an unparalleled example of the scale of landscape engineering associated with pre-Columbian polities. It is the largest contiguous area preserving living descendants of these complex societies continue to practice traditional livelihood strategies (Heckenberger, 2005, 2010; Schwartzman et al., 2013). The implication is that much of the protected corridor, which represents major rivers and closed tropical forests, is dominated by anthropogenic forest, representing distinctive areas of complex socio-ecological systems and sensitivity to large-scale contemporary drivers within and around indigenous areas. In other words, to greater and lesser degrees, the entire forested core of the basin was an anthropogenic landscape influenced by past and present human actors. Like other anthropogenic 
landscapes of the southern Amazon, the Upper Xingu is a critical sites of cultural, historical, and biodiversity heritage, but are not widely recognized as global heritage and strategies for their preservation are overshadowed by conservation of areas of presumed natural forest. In these areas, environments are more socially heterogeneous and ecologically patchy, which can increase overall biodiversity, in terms of both species diversity and ecological heterogeneity (Balée, 2006; Balée \& Erickson, 2006; Posey, 2002), and also offer ready solutions to questions of ecological resilience, measured in terms of bio-historical diversity, and the sustainability of certain practices in the face of dramatic change in regional systems.

The Xingu River basin $\left(510,000 \mathrm{~km}^{2}\right)$ straddles three major transitional zones: the closed evergreen forests of in the lower Amazon River, more open evergreen forests and woodland transitions of southeastern Brazil and the southern transitional deciduous forests (Figure 1B). Over half of the basin lies within contiguous protected areas, the Xingu corridor, which is composed of 21 demarcated indigenous areas and 10 wildlife protected areas $\left(\sim 290,000 \mathrm{~km}^{2}\right)$, which comprises the largest contiguous area of indigenous lands and protected areas in the Amazon. Areas within the protected corridor are still verdant, but an explosion of deforestation from cattle ranching, soy farming and urbanization, including current and future implementation of hydro-electric projects, has devastated forests on the frontier of the Xingu corridor turning the region drier and vulnerable to forest fires and other climate change effects (Nepstad et al., 2006).

Studies in archaeology and indigenous history highlight important questions of variability and scale in reconstructions of heterogeneous regimes of land-use (Denevan, 1992, 2001). Forest conversion by pre-Columbian settled agriculturalists do leave obvious indicators in soils, such as carbonized botanical remains and micro-botanical remains, but minimal on-site sampling fails to recognize substantial variability within regions (e.g. Woods et al., 2009). In addition to the Amazon floodplain region (várzea), several areas of transitional tropical forest areas, such as seasonally inundated areas, including portions of the Bolivian and Venezuelan llanos and coastal Guianas, and the upland forests and open landscapes of the southern peripheries. Recent research in the southern Amazon has produced substantial evidence of large, densely settled populations and complex regional organization, which had large-scale anthropogenic impacts on the natural environment. It also suggests complex socio-historical diversity, including areas of small size and low density of occupations sites in 
sparsely populated hinterlands and "buffer zones," such as uplands surrounding the upper Xingu and Tapajós rivers.

The southern transitional forests (approximately 5\% of the Amazon basin or size of the várzea), complex built environments are widely known in riverine areas of the southern headwaters. Early ethno-historic reports (1600-1850) describe regional Arawak-speaking enclaves across the southern transitional forests as large, densely settled populations, the remnants of socio-politically integrated pre-Columbian regional systems (Block, 1994; Denevan, 1966; Oliveira, 1968). The Upper Xingu is the easternmost of these regional archaeological cultures of Arawak affiliation spread across the southern transitional forests of Amazonia. Archaeology in this area has documented discrete late pre-Columbian, recent historical and contemporary contexts in landscapes that show a continuous record of habitation by related (Xinguano) peoples over the past millennium.

Archaeological research suggests several major periods of transformational change in this regional system (supported by $30 \mathrm{C} 14$ dates): $:^{1}$ (1) pre-Galactic Period colonization by settled agriculturists by ca. 1500 BP, or before (initial Xinguano Tradition;); (2) Galactic Period enlargement and structural elaboration of major settlements, ca. 1350 to 1650 , marked by large-scale constructions (roads, canals, weirs, ponds, defensive walls, and other engineered features) and inferred integration in hierarchical clusters; (3) Transitional Period population decline and fallowing of the forest landscapes, after ca. 1550-1700; (4) Early Xinguano Period marked geographic compression, ethnogenesis and reconstitution of multi-ethnic society, from 1700-1884 continued occupation and reoccupation of pre-Columbian sites but scale-adjusted in regional settlement systems due to continued depopulation from early regional colonization by Europeans in the eighteenth and nineteenth centuries; (5) Historical Xinguano Period post-1884 after Xinguano peoples enter the written record, which between the 1880s and 1980s had lost $80 \%$ of their population; (6) Contemporary Xinguano post-1980 demographic and socio-economic rebound and re-stabilization and greater political self-determination (Heckenberger, 2005).

Research on the archaeology and indigenous history of the Upper Xingu was initiated in 1992, with the institutional sponsorship of the Museu Nacional, Universidade Federal do Rio de Janeiro (UFRJ). Since 2001, the interdisciplinary project is co-directed by Heckenberger and Drs. Bruna Franchetto and Carlos Fausto (UFRJ) and combines archaeology, ethnography, and linguistics, within an overall program of collaboration aimed at documentation of cultural heritage and indigenous education by the AIKAX: Associação Indígena Kuikuro 
do Alto Xingu (Fausto et al., 2008; Franchetto \& Heckenberger, 2001; Franchetto, 2011; Heckenberger, 2005).

Indigenous research assistants were trained and participated in all archaeological investigations (Heckenberger, 2007, 2009). Indigenous research assistants were critical to identify historical villages (etepe) and ancient settlements (ingiholó-itupe), locating earthworks, anthropogenic dark earth (egepe) and related distinctive vegetation, and ceramics (egeho), which are all closely correlated (Heckenberger, 2006, 2009; Schmidt, 2010). Once located, all sites were positioned with differential GPS or on satellite images (in those few cases where GPS was not available). Major earthworks were GPS mapped at 10 sites (roughly $40 \mathrm{~km}$ of continuous archaeological features). Basic mapping of major earthworks was conducted in and around select sites $(n=14)$, including ditch/berm systems and linear berms (.5 to $2 \mathrm{~m}$ high), situated at the margins of major roads ( $>10 \mathrm{~m}$ wide) and circular public plaza areas. Detailed mapping of earthworks was conducted at eight sites (X6, X13, X11, X17-20, X22).

Participatory survey and mapping of suggest that most if not all of the identified residential sites (28) were associated with two internally hierarchical clusters, ca. 1300-1650 (Figure 2). It is inferred that these were linked territorial polities. In the better known northern (Ipatse) cluster, settlements were positioned at forest/wetland interfaces at regular intervals $(3-8 \mathrm{~km})$ and linked by a region-wide system of broad, straight roads. Clusters were composed of large- $(\geq 40 \mathrm{ha})$ and medium-sized ( $<30 \mathrm{ha})$ plaza towns, smaller $(<10 \mathrm{ha})$ plaza villages, and small (non-plaza) hamlets. Plaza towns were distinguished by major ditches (500-2000+ m long), defining settlements boundaries, associated with a palisade wall, and, in some cases, located within settlements. Mapping of major earthworks at these sites reveals an elaborate regional plan, including major excavated ditches surrounding largest settlements (up to $15 \mathrm{~m}$ wide, $5 \mathrm{~m}$ deep, and $2.5 \mathrm{~km}$ in length), linear mounds positioned along roads and public plaza areas, and a variety of wetland constructions, such as raised causeways, bridges, river obstructions (weirs), canals, and artificially modified ponds. Extensive residential occupations are documented across interior portions of walled settlements, including structural remains (house and trash midden areas) and ceramic cooking utensils, covering $\geq 20$ ha in first-order settlements. Small non-walled plaza villages are similar in size and form to contemporary villages.

In addition to their larger size and structural elaboration, including gates, roads, and secondary plazas (possible ritual staging areas), walled towns are distinguished by their position in relation to the cluster center: largest residential centers are located roughly equidistant $(3-5 \mathrm{~km})$ from the exemplary center 
(X13) to the NW and SE and medium-sized centers to the NE and SW, roughly 8-10 km from center. The area enclosed by the primary satellites represents the core area of each galactic cluster (an autonomous polity in the regional peer polity), with smaller non-walled settlements situated in a hinterland area. Earthen dams used as weirs and causeways, artificially modified ponds, and bridges and bridge abutment have been identified associated with major roads and settlements.

These findings generally confirm the large size of late prehistoric communities, including accretional deposits across most areas of the site, including areas of high and low frequency and identifiable function (house, ADE midden, public space, work, traffic and non-ADE gardening areas (Schmidt, 2010; Toney, 2012). Specifically, it predicts a pattern of highly standardized land-use, including the regular spacing of clusters across the region, precise orientation of settlements within clusters and rigidly partitioned or zoned areas of land-use in developed core areas and more lightly occupied managed forests and closed forest buffer areas. Elements of this system are preserved among descendant groups, but, if predictions are correct, ancestral late pre-Columbian socio-political formations (ca. 1250-1650 CE) represent a high level of regional planning and environmental engineering in forested regions of Amazonia, including semi-intensive subsistence agriculture, industrial plants and timber, as well as wetland management, creating a complex mosaic of land-use.

Archaeology, at least as a set of technical skills and shared inclinations based on them, is uniquely suitable, and critical for addressing related issues of indigenous history, ecology and sustainability research. The Xingu is the only place where these groups are linked in an unbroken tract of intact Amazonian forest. It also informs contemporary patterns in novel ways, such as an inversion between traditional forest management in low-lying areas of the basin and tied to major rivers, now under indigenous control, and threatened by large-scale economic development along the uplands at the peripheries, with the axis being topographic divides. The basic assumption is that these cannot be understood without placing ecological studies in the context of pre-Columbian and historic human occupations. The project develops research strategies focused on partnership and training with descendent communities, whose livelihoods depend on the integrity of Xingu socio-ecological landscapes and are most directly responsible for their preservation. 


\section{Context-sensitive science $\&$ collaboration}

Currently, the most critical challenge for sustainability science is to develop robust linkages between ecological and historical science and between scientific research and indigenous peoples, NGOs, and the broader public, including the establishment of networks, standardization of data collection, storage, and sharing, and training of indigenous and other local participants for socio-environmental monitoring and management of indigenous and other protected areas. Participation by local communities, at the very least, is a critical feature of resource management and conservation in tropical forest areas. As Alcorn and Zarzycki (2005:12) suggest: "if we are really concerned about the loss of biodiversity, new paradigms of collaboration are needed to address this crisis, not more catchwords. Non-indigenous society needs to acknowledge the challenge of representation and communication across cultures."

Nonetheless, despite a remarkable rise in research in all disciplines, there is little articulation between historical and ecological research and the dialogue between scientists and indigenous peoples is often poorly developed, short-lived and even divisive. In indigenous and associated protected areas, which constitute $>20 \%$ of the Brazilian Amazon (Nepstad et al., 2006), scientific research must proceed in dialogue with local communities and practices.

In the Xingu corridor, in particular, such engaged approaches are an imperative to conduct scientific research, but recent forums sponsored by ISA and EDF in Altamira in 2011 and 2013 show resounding support to create collaborative networks. As critical players in the discussion of sustainable prosperity and human rights tied to major global initiatives of biodiversity conservation and forest restoration, such as the United Nations REDD+ programs, NGOs and the local groups they work with provide not only necessary stakeholders that most $\mathrm{e}$ consulted but also important human resources that provide novel perspectives and practices for developing meaningful and responsible solutions to pressing problems.

These participatory techniques provide the basis for indigenous integration, articulated to the annual regional workshops and web-based network interaction, including interactive GIS. Two Altamira conferences provided some mandate by indigenous communities that the best scientific research is highly desirable to all parties, but within the context of a network that includes diverse local groups. Integrated training and mapping will proceed in a way that permits novel interpretations and problems to emerge within the open collaborative network. The project involves satellite image analysis, GIS and ground-based mapping in 
training workshops that incorporate human occupational and ecological data and specific spectral "signatures" of suggested anthropogenic influence.

Indigenous groups invariably know where major cultural sites are located and often have detailed knowledge of their place in local ecological and historical contexts. What they do not know is how to record and map them. In archaeological studies collaboration develops through co-produced geo-spatial data collection and interpretation techniques. This spatial data and maps, based on robust GPS and supporting supplementary meta-data and GIS, provide a scaffolding to bridge temporal scales from centennial ethnographic and oral historical scales to the millennial scales of archaeology, historical ecology and paleoecology to the shorter time frames and recent patterns. Through the establishment of protocols for field training, cultural heritage mapping and spatial science and interdisciplinary studies are aimed at developing systematic measures of forest cover alteration over the past millennium or more.

Participatory GPS cultural heritage mapping also provides a solid basis for classification of satellite images, which in turn will provide patterns that can be investigated through ground-based studies and refining interpretations anthropogenic patterns of vegetation and land-cover and land-use change through time. Satellite image analysis has been ongoing since 2001 in the Upper Xingu project, culminating in a predictive model to highlight areas with anthropogenic vegetation (Figure 3C; Russell, 2005). Specific "regions of interest" (ROI) were established for field training and initial classification of satellite images and initial synthetic descriptive maps and predictive models for each study area (Russell, 2005). Analyses of available satellite imagery, maps and documents, notably professional ethnographies, provides the basis to develop historically sensitive spatial data, which will create the common basis to develop further trans-disciplinary and specialized research. Archaeological mapping in ROIs, in particular, focuses on identification and characterization of anthropogenic soils and other obvious disturbance indicators, which can be further classified through paleo-ecological, ecological and ethno-ecological studies.

Initial models from remote sensed data of settlement pattern and land-use (as seen through analysis of forest cover in classified satellite images) can be applied to new areas in the Xingu and elsewhere in Amazonia. Remote-sensed data and rapid assessment protocols are critical not only in understanding the Xingu basin but as a proxy measure for categorizing, at least heuristically, other areas in the southern Amazon. What is critical is designing research strategies based on commensurate baseline data. The assumption is that all research requires some basic spatial component, which is a primary dimension of comparison 
across disciplines. Archaeologists are well-suited to mapping cultural heritage and anthropogenic features, which, coupled with satellite imagery and high-resolution GPS in the Amazon over the past decade, provides robust framework of locally co-produced knowledge, including archaeological and spatial science tied to the ethno-ecology and oral history of these living traditions.

In short, in order to address multi-scalar questions of resilience or sustainability, particularly balancing economic, ecological and social factors, research in indigenous areas requires not only engagement but full collaboration in research design, implementation and data management and dissemination. The problem is often a question of translation between local practices and interests, and those of major NGOs and scientific researchers, notably within the broader arenas of conservation and development, sustainability studies, and globalization, notably Brazilian and international initiatives (e.g., REDD+) to protect and potentially restore degraded landscapes, including areas of the Xingu basin outside of the protected corridor (Stickler et al., 2008).

What are most urgently needed, at all scales, are well-integrated research networks based on context-sensitive approaches that include research on natural and cultural resources and co-design of integrated management plans with local communities and regional NGOs. Two meetings in Altamira in 2011 and 2013, sponsored by ISA and ESF, underscore this common goal in the Xingu corridor: to develop coalitions linked to the best science possible. The intention is to establish acceptable and accessible research protocols and synergies between participants, including interdisciplinary topics and more broadly in terms of NGO and local capacity building. The general approach developed in the participatory research in the Upper Xingu (Fausto et al., 2008; Franchetto, 2011; Heckenberger, 2007, 2009) can be easily extended to research-training sites in indigenous areas in other areas. This involves learning through doing and capacity building, aimed at doing - the job of finding scientifically robust and socio-culturally responsible approaches to sustainability - through mutual learning, providing a common framework for collection of geo-spatial data, widely accessible to diverse partners.

This focus on context-sensitive approaches, where problems are revealed through the space/place-based contexts themselves, aims to provide advances and solutions to context-specific issues and problems. These inform general theoretical models and broader strategies for robust and responsible sustainability. The Xingu corridor represents a large-scale context for considering the practical and ethical imperatives of working with descendant populations. This in no way compromises the production of robust research, in fact it improves 
the capacity to do fundamental science, insofar as the methodological foundation is based on partnerships, including inter-disciplinary and trans-disciplinary strategies and, most importantly, descendant populations.

In the Xingu corridor, a specific aim is to create dialogic communities of knowledge production that actively engage indigenous and other traditional peoples and NGOs in fully collaborative partnerships (Heckenberger, 2007, 2009; Pound et al., 2003; Schwartzman and Zimmerman, 2005). Specifically what is needed now is to develop an integrated framework for participatory cultural heritage research with indigenous groups, including most or all of the 24 principle indigenous groups in the Xingu protected corridor, and link these to larger scientific and public networks through academic institutions and NGOs in Brazil and internationally. Such research networks, including integrated scientific researchers, indigenous and rural partners, and NGOs, are critical to address link large-scale drivers, such as economic development and climate change, with regional and local responses and interactions. The contiguous protected forest areas is itself a large-scale driver that cannot be understood without reference to its history or without direct local participation at all levels of research, since it is largely under indigenous occupation and control.

The Upper Xingu provides one model for strategies to document cultural heritage resources, including contemporary occupation and land-use, through participatory mapping and rapid assessment protocols conducted across the protected corridor. This geo-spatial mapping easily links with broader networks, such as ISA and their partner's diverse Xingu Corridor projects. These studies would also inform strategies for monitoring linked human-natural systems and evaluate change in them over time. Specifically, what are currently most needed is integrated research groups, that include: (1) a formal network of interdisciplinary scholars with diverse backgrounds in the social and natural sciences; (2) standardized geo-spatial data bases from widely available orbital imagery and regional GIS across the basin, conducted in partnership with indigenous and rural communities through participatory GPS mapping and local interactive GIS; (3) clear strategies of collaboration and protocols for scientific data collection for research and environmental monitoring, including local education manuals and skills training, notably identification, mapping, and monitoring of key sites, and long-term management of the diverse landscapes of the corridor. 
A.

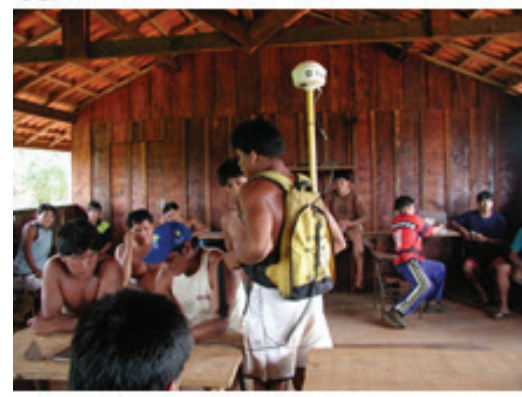

B.

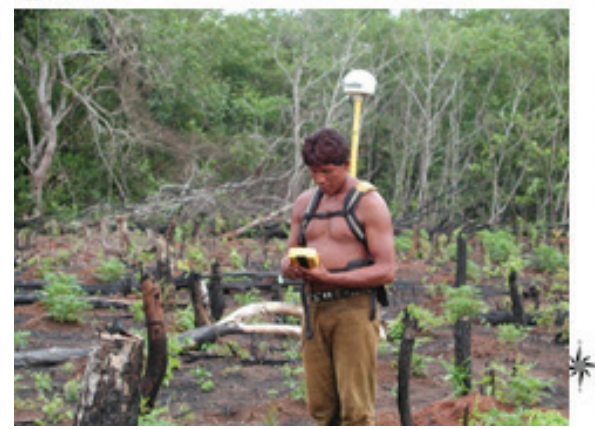

C

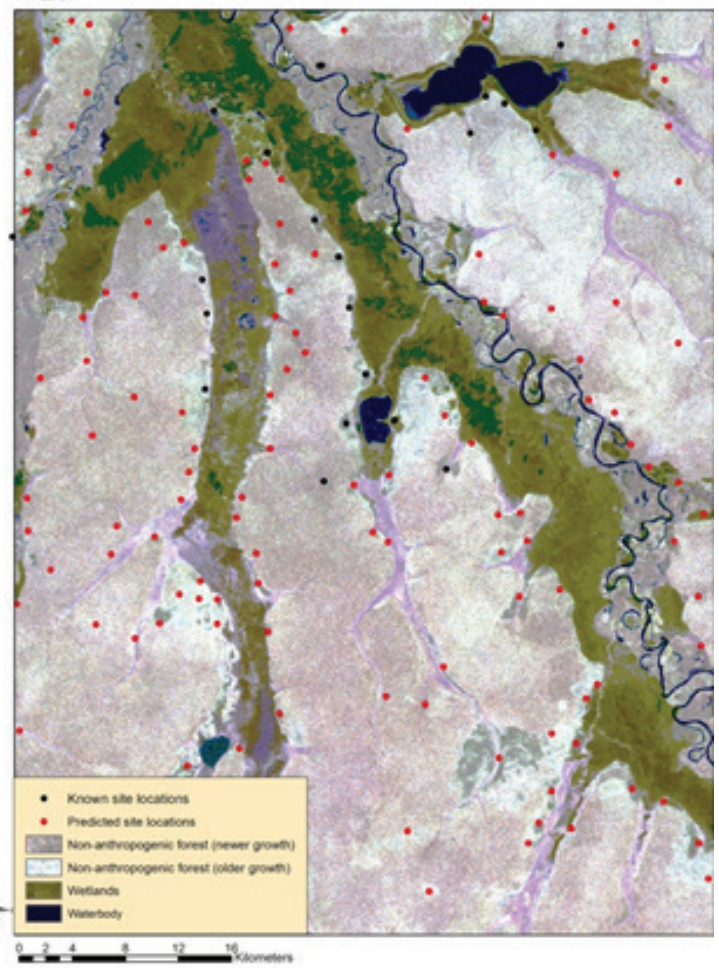

Figure 3. A. GPS training workshop in Kuikuru village; B. Laquai Kuikuro dGPS mapping; C. Predicted (red dot) and known (blue dot) site locations within the Kuikuro study areas, Upper Xingu (forested areas are whitish in color; wetlands greenish; reproduced from Russell, 2005).

\section{Archaeologies of the future}

Given the massive scale of tropical deforestation today and all of its important social and economic implications, it is imperative that we improve our historical understanding of tropical ecosystem dynamics in settings that include, not exclude, people. In the southern Amazon, transitional forests have fallen to a fraction of their original size (20\%), much of which is in indigenous areas (Nepstad et al., 2006; Schwartzman et al., 2000, 2013). Locally developed current indigenous resource management systems, or thus reconstructed from the past, provide alternative models of land-use for present and future human generations. This is particularly critical in transitional areas, such as those in the Xingu, which are demonstrably dynamic, in some cases oscillating between forested and woodland or even grassland states (Staver et al., 2011), and sensitive to human influence, including grasslands management with fire and 
hydrological engineering in non-forested areas and forest islands (Denevan, 2001; Posey, 2002).

Mapping is not only quantitative, hyper-quantitative, in fact, and easily accessible to different participants. It is widely used to address large social masses or geographies. However, the goal of most spatial mapping is tied to actual places, contexts, which are socially, culturally and historically defined. The aim is thus more qualitative in providing talking points and contextual detail, rather than confirmation (or not) of deduced patterns. The approach advocated here, as a model for more general applications, not only builds on indigenous knowledge of historical places and anthropogenic indicators, such as soils, vegetation, faunal communities and interactions between them, generally anchored to broader hydrological systems and cultural models, but incorporates it in future research design and implementation.

The future aim is to develop collaborative management and monitoring strategies that can be applied elsewhere in Amazonia and has a transformative impact by engaging diverse stakeholders in the trans-disciplinary and multi-cultural co-production of knowledge. Methods are informed by both scientific and indigenous knowledge, but specifically designed to articulate with broader global scientific initiatives, such as biodiversity conservation and reduced tropical forest degradation programs (e.g., UN REDD+). Finding alternative strategies, such as extractive resource management, are critical and it is here that indigenous perspectives offer considerable value, particularly considering their historical development and performance over the long-term. Evidence that degraded tropical forest landscapes can be restored (Lamb et al., 2005) by incorporating alternatives to clear-cutting further underscores the critical value of understanding indigenous agricultural practices, particularly as they relate to densely settled, agricultural populations suggested in several areas. Devising alternatives for environmental management and conservation with people that hold deep experiential knowledge of coupled human-natural systems enhances the potential application of research outcomes and protocols in fostering sustainability in the Amazon.

Archaeology helps provide critical baseline data for development of an integrated management plan for the watershed with strategies tailored to local and regional socio-environmental features. It is novel in terms of integrating knowledge and studies in biological diversity, ecology and contemporary economic development with those of historical ecology, including archaeology, paleoecology, ethnoecology, indigenous history and traditional environmental engineering systems. It also attends to multiple scales and perspectives in multi-vocal 
research contexts. Robust participatory research, notably GPS mapping and GIS, aims to integrate local and scientific views to design robust scientific research that is meaningful to diverse groups and attends to environmental, economic and social aspects of sustainable development in the Amazon.

In other words, anthropological archaeology is a key point of articulation between natural and social sciences, an interpretive and translation space. In an anthropological sense it looks back to look forward, and then forward to look back, and by its very eclectic nature tends to share a general trend in social theory in anthropology: theory is what we disagree on, as opposed to that of the natural sciences, where it is what is seen as a given. Scale, perspective and voice intervene, again and again, redefining the divides that structure our knowledge production industries with the overall urban fabric of the modern world, particularly Brazil's meteoric rise in economic power in the late $20^{\text {th }}$ and $21^{\text {st }}$ century. For the anthropologist, archaeologist in training or not, the question is: what should the "archaeologies of the future" look like, borrowing Jameson's (2005) apt phrase, recalling that history is always as much about forgetting as remembering in pressing the "desire called utopia and other science fictions." One view of that future, suggested by Paulo Freire nearly 50 years ago in what later he called the "pedagogy of hope" (1994), inspires participatory action research and inclusive strategies of knowledge production, and reminds us that some things should not be forgotten. Simply put, everyone benefits by putting research in the hands of indigenous peoples, as full partners in its design and deployment as we all struggle with urgent issues in sustainability, climate and poverty in the Amazon.

\section{Acknowledgements}

Regional survey and rapid site assessment and archaeological testing were conducted with the Kuikuro indigenous community with NSF support to the PI from 1992-1994 and 2002-2006 (BCS 0004497; BCS 0353129). Bruna Franchetto and Carlos Fausto (PPGAS, Museu Nacional) are the principle Brazilian partners in research, which also included archaeological support from Edithe Pereira and the Museu Paraense Emílio Goeldi. The ideas expressed here were also strongly influenced by several other colleagues in Brazil, particularly Eduardo Neves, Andre Villas-Boas, Fabíola Silva, Cristiana Barreto, and Juliana Machado, and in the USA, especially Simone Athayde, Stephen Schwartzman, Morgan Schmidt, Joshua Toney, Christian Russell, and Anna Brown Ribeiro. In addition to support from NSF, the William Talbott Hillman Foundation provided critical support to the overall project. All are thanked for their gracious 
support, particularly Chief Afukaka, his family and the Kuikuro community, who have since the start been critical co-designers of research results and interpretation, although they may not agree entirely with all the conclusions presented in this paper.

Recebido em: 24 de agosto de 2014

Aceito em: 27 de setembro de 2014

Michael Heckenberger is an Associate Professor in Anthropology at the University of Florida. He work with the Kuikuro indigenous community over the past 25 years has focused on participatory cultural heritage mapping and archaeological testing in the Parque Indígena do Xingu. This work aims to understand long-term dynamic change in coupled human-natural systems and use this knowledge to address contemporary issues of culture heritage and socio-ecological sustainability in the Amazon. He has also conducted research in several other parts of the Brazilian Amazon, Guyana, and the Caribbean.

\section{Notes}

1. Field research to date in the Kuikuro study area $\left(\sim 1200 \mathrm{~km}^{2}\right)$, summarized in Heckenberger 2005, 2013) has involved: (1) settlement survey and satellite real-time (differential) dGPS (Trimble XRS) positioning of 28 pre-Columbian sites and historic settlements (1750-present) within them (Figure 3); (2) dGPS-based mapping of earthworks at major late pre-Columbian settlements (e.g., X6, X13, X18, and others); (3) extensive test excavation at two sites (X6 and X13), block excavation of one house structure (340 $\mathrm{m}^{2}$ ) C14 dated to ca. 1450 at X6 and limited test excavation and soil sampling at additional pre-Columbian sites (X11, X14, X15, X18); and (4) project GIS. Previous research included detailed studies of ADE and household production and archaeological ceramics, including testing in current and recently occupied Kuikuro settlements (Schmidt 2010; Toney 2012). Additionally, five lake-bottom sediment cores were raised from a large lake, a small lake and pond/bogs adjacent X6, X13 and X18. These contained well-preserved pollen with five $\mathrm{C} 14$ dates from 30,000 BP to $5500 \mathrm{BP}$, with a notable transition from majority grasses to current forested conditions estimated at ca. 3500 BP (M. Bush [FIT], J. Curtis [UF Geology), P. Oliveira [USP], pers. comm., 2006-2012). 


\section{References}

ALCORN, Janis. \& ZARZYCKI, A. 2005. "Response to Chapin: a Challenge to Conservationists: Phase II". World Watch, 11-13.

ASHBY, Jacqui. 2003. "Introduction: Uniting Science and Participation in the Process of Innovation - Research for Development”. In: Barry Pound et al. (eds.). Managing Natural Resources for Sustainable Livelihoods: Uniting Science and Participation. London: Earthscan. pp. 1-19.

BALÉE, William. 1989. "The Culture of Amazonian Forest”. Advances in Economic Botany, 7:1-21. (Resource Management in Amazonia: Indigenous and Folk Strategies).

. 2006. "The Research Program of Historical Ecology". Annual Review of Anthropology, 35:75-98.

. (ed.). 2010. Long-term Anthropic Influences on Diversity of Amazonian Landscapes and Biota. Diversity, Special Issue.

2013. Cultural Forests of the Amazon: a Historical Ecology of People and their Landscapes. Tuscaloosa: University of Alabama Press.

BALÉE, William \& ERICKSON, Clark L. (eds.). 2006. Time and Complexity in Historical Ecology: Studies in the Neotropical Lowlands. New York: Columbia University Press.

BERKES, Fikret \& FOLKE, Carl. 1998. Linking Social and Ecological Systems for Resilience and Sustainability. In: - Linking Social and Ecological Systems: Management Practices and Social Mechanisms for Building Resilience. Cambridge: Cambridge University Press. pp. 1-25.

BLOCK, David. 1994. Mission Culture on the Upper Amazon: Native Tradition, Jesuit Enterprise and Secular Policy in Moxos, 1600-1880. Lincoln: University of Nebraska Press.

BRONDIZIO, Eduardo; OSTROM, Elinor \& YOUNG, Oran. 2009. "Connectivity and Governance in Multi-level Socio-Ecological Systems: the Role of Social Capital”. Annual Review of Environmental Resources, 34:253-278.

BUSH, Mark B. et al. 2008. "Fire, Climate Change and Biodiversity in Amazonia: a Late-Holocene Perspective”. Philisophical Transactions of the Royal Society B, 363:1795-1802.

CHAPIN, Mac. 2004. "A challenge for conservationists”. World Watch, 17-31.

CLEARY, David. 2001. "Toward and Environmental History of the Amazon: From Prehistory to the Nineteenth Century”. Latin American Research Review, 36:65-96. 
CLEMENT, Charles. R. 1999. "1492 and the Loss of Amazonian Crop Diversity: I. The Relation between Domestication and Human Population Decline”. Economic Botany, 53:12-25.

DAVIDSON, E. A. et al. 2012. “The Amazon Basin in Transition”. Nature, 481,321-328.

DENEVAN, William. 1966. The Aboriginal Cultural Geography of the Llanos de Mojos of Bolivia. Berkeley and Los Angeles: University of California Press.

1992. "Stone vs. Metal Axes: the Ambiguity of Shifting Cultivation in Prehistoric Amazonia”. Journal of the Steward Anthropological Society, 20(1+2):153-165.

2001. Cultivated Landscapes of Native Amazonia and the Andes. New York: Oxford University Press.

DULL, Robert, et al. 2010. "The Columbian Encounter and the Little Ice Age: Abrupt Land Use Change, Fire, and Greenhouse Forcing". Annals of the Association of American Geographers, 100(4):1-17.

ERICKSON, Clark L. 2006. “The Domesticated Landscape of the Bolivian Amazon”. In: William Balée \& Clark L. Erickson (eds.). Time and Complexity in Historical Ecology. New York: Columbia University Press. pp. 235-278.

ERICKSON, Clark L. \& BALÉE, William. 2006. “The Historical Ecology of a Complex Landscape in Bolivia”. In: William Balée \& Clark L. Erickson (eds.). Time and Complexity in Historical Ecology: Studies in the Neotropical Lowlands. New York: Columbia University Press. pp. 187-234.

FAUSTO, Carlos; FRANCHETTO, Bruna \& HECKENBERGER, Michael J. 2008. "Language, Ritual and Historical Reconstruction: Towards a Linguistic, Ethnographical and Archaeological Account of Upper Xingu Society”. In: K. David Harrison, David Rood \& Arienne Dwyer (eds.). Lessons from Documented Endangered Languages. Amsterdam: John Benjamins. pp. 129-157.

FISHER, Christopher T. \& FEINMAN, Gary M. 2005. "Introduction to 'Landscapes over Time'”. American Anthropologist, 107(1):62-69.

FOLKE, Carl. 2006. "Resilience: the emergence of a perspective for social-ecological systems analyses”. Global Environmental Change, 16(3):253-267.

FRANCHETTO, Bruna (ed.). 2011. Alto Xingu: uma Sociedade Multi-lingue. Rio de Janeiro: Museu Nacional. 
FRANCHETTO, Bruna \& HECKENBERGER, Michael J. (eds.). 2001. Os Povos do Alto Xingu: Cultura e História. Rio de Janeiro: Editora UFRJ.

FREIRE, Paulo (1994), Pedagogy of Hope: Reliving Pedagogy of the Oppressed. New York: Continuum.

GEZON, Lisa L. \& PAULSON, Susan. 2005. "Place, Power, Difference: Multi-scale Research at the Dawn of the Twenty-first Century”. In: Susan Paulson \& Lisa L. Gezon (eds.). Political Ecology across Spaces, Scales, and Social Groups. New Brunswick: Rutgers University Press. pp. 1-16.

GUNDERSON, Lance H. 2000. "Ecological Resilience - in Theory and Application". Annual Review of Ecology and Systematics, 31:425-439.

GUNDERSON, Lance H. \& HOLLING, C.S. (eds.). 2002. Panarchy: Understanding Transformations in Human and Natural Systems. Washington: Island Press.

HECHT, Susanna. 2003. "Kayapo soil management strategies”. In: Johannes Lehmann, Dirse Kern \& William Woods. Amazonian Dark Earths: Origins, Properties, and Management. Dordrecht: Kluwer Academic Publishers.

. 2013. The Scramble for the Amazon and the "Lost Paradise" of Euclides da Cunha. Chicago: Chicago University Press.

HECHT, Susanna. B., Kathleen D. Morrison and Christine Padoch., eds. (2013). The Social Lives of Forests: Past, Present and Future of Woodland Resurgence. Chicago: University of Chicago Press.

HECKENBERGER, Michael J. 2005. The Ecology of Power: Culture, Place, and Personhood in the Southern Amazon, A.D. 1000-2000. New York: Routledge.

2006. "History, Ecology, and Alterity: Visualizing Polity in Ancient Amazonia”. In: William Balée \& Clark L. Erickson (eds.). Time and Complexity in Historical Ecology: Studies in the Neotropical Lowlands. New York: Columbia University Press. pp. 311-340.

. 2007. "Entering the Agora: Archaeology, Conservation and Indigenous Peoples in Amazonia”. In: Colwell-Chanthaphonh, Chip; Ferguson, T. J. (eds.). Collaboration in Archaeology: Working with Descendent Populations. Altamira, Lanham, MD. pp. 234-272 .

2009. "Mapping Indigenous History: Cultural Heritage, Conservation, and Collaboration in the Amazon”. Collaborative Anthropologies, 2: 9-32.

2010. "Bio-Cultural Diversity in the Southern Amazon”. Diversity, 2(1):1-16. 
2013. Kuikuro Ethno-Archaeology: Graphic Report on Investigations (2002-2006). Ms. available online, UFlorida, Gainesville, FL.

HECKENBERGER, Michael J. \& NEVES, E. G. 2009. "Amazonian Archaeologies”. Annual Review of Anthropology, 38:251-266.

HECKENBERGER, Michael J. et al. 2003. “Amazonia 1492: Pristine Forest or Cultural Parkland". Science, 301:1710-1714.

2007. "The Legacy of Cultural Landscapes in the Brazilian Amazon: Implications for Biodiversity”. Philosophical Transactions of the Royal Society London B: Biological Sciences, 362(1478):197-208.

2008. "Pre-Columbian Urbanism, Anthropogenic Landscapes and the Future of the Amazon”. Science, 321:1214-1217.

HODDER. Ian. 2012. Entanglement: an Archaeology of the Relationship between Humans and Things. London: Wiley-Blackwell.

INGOLD, Tim. 2001. The Perception of the Environment: Essays on Livelihood, Dwelling and Skill. London: Routledge.

2013. Making: Anthropology, Archaeology, Art and Architecture. London: Routledge.

JAMESON, Fredric. 2005. Archaeologies of the Future: the Desire Called Utopia and Other Science Fictions. London: Verso.

KENNEDY, Donald. 2004. "Editorial: Climate Change and Climate Science”. Science, 304(5677):1564-1565.

LAMB, David et al. 2005. "Restoration of Degraded Tropical Forest Landscapes". Science, 310:1628-1632.

LAURANCE, William F. et al. 2001. "The Future of the Brazilian Amazon”. Science, 291:438-439.

MARTENS, Pim 2006. “Sustainability: Science or Fiction?” Sustainability: Science, Practice, \& Policy, 2(1):36-41.

MASON, Betsy. 2004. “The Hot Hand of History”. Nature, 427:582-583.

NEPSTAD, Daniel. et al. 2006. "Inhibition of Amazon Deforestation and Fire by Parks and Indigenous Lands". Conservation Biology, 20(1):65-73. 
NEVES, Eduardo G. \& PETERSEN, James B. 2006. "The Political Economy of Pre-Columbian Amerindians: Landscape Transformations in Central Amazonia”. In: William Balée \& Clark L. Erickson (eds.). Time and Complexity in Historical Ecology: Studies in the Neotropical Lowlands. New York: Columbia University Press.

OLIVEIRA, Roberto Cardoso de. 1968. Urbanização e tribalismo: a integração dos índios Terêna numa sociedade de classes. Rio de Janeiro: Zahar.

POSEY, Darrell. 2002. Kayapo Ethnoecology. Oxford: Oxford University Press.

POSEY, Darrell. A. \& BALÉE, William. 1989. Resource Management in Amazonia: Indigenous and Folk Strategies. Bronx, New York: The New York Botanical Garden.

POUND, Barry et al. (eds.). 2003. Managing Natural Resources for Sustainable Livelihoods. Uniting Science and Participation. London: Earthscan.

PRETTY, Jules. et al. 2009. "The Intersections of Biological Diversity and Cultural Diversity: Towards Integration”. Conservation \& Society, 7(2):100-112.

RAMOS, Alcida R. 1998. Indigenism: Ethnic Politics in Brazil. Madison: University of Wisconsin Press.

REDFORD, Kent H. \& SANDERSON, Steven E. 2000. "Extracting Humans from Nature”. Conservation Biology, 12:1362-1364.

REDMAN, Charles. 2005. "Resilience Theory in Archaeology". American Anthropologist, 107:70-77.

REDMAN, Charles L. \& KINZIG, Ann. 2003. "Resilience and Past Landscapes: Resilience Theory, Society, and the Longue Duree”. Conservation Ecology, 7:14. Available from: http://www.consecol.org/vol7/iss1/art14. Accessed on November 4, 2006.

ROSTAIN, Stéphen. 2012. Islands in the Rainforest: Landscape Management in Pre-Columbian Amazonia. Walnut Creek: Left Coast Press.

RUDDIMAN, William F. 2003. "The Anthropocene Greenhouse Era Began Thousands of Years Ago", Climatic Change, 61:261-293.

. 2013. "The Anthropocene". Annual Review of Earth and Planetary Sciences, $41: 401-424$.

RUSSELL, Joseph C. 2005. Integrated Approach to Predictive Modeling: a Case Study from the Upper Xingu (Matto Grosso, Brazil). PhD Dissertation, University of Florida. 
SCHAAN, Denise. 2011. Sacred Landscapes of Ancient Amazonia: Historical Ecology of Social Complexity. Walnut Creek, CA: Left Coast Press.

SCHMIDT, Morgan J. 2010. Reconstructing Tropical Nature: Prehistoric and Modern Anthrosols (Terra Preta) in the Amazon Rainforest, Upper Xingu River, Brazil. PhD Dissertation, University of Florida.

SCHMINK, Marianne. 2011. "Forest Citizens: Changing Life Conditions and Social Identities in the Land of the Rubber Tappers". Latin American Research Review, 46:141-158.

SCHMINK, Marianne \& WOODS, Charles H. 2013. Contested Frontiers in Amazonia. New York: Columbia University Press.

SCHWARTZMAN, Stephan \& ZIMMERMAN, Barbara. 2005. "Conservation Alliances with Indigenous Peoples of the Amazon”. Conservation Biology, 3:721-727.

SCHWARTZMAN, Stephan et al. 2000. "Rethinking Tropical Forest Conservation: Perils in Parks”. Conservation Biology, 12:1351-1355.

2010. "Social Movements and Large-Scale Tropical Forest Conservation on the Amazon Frontier: Conservation from Chaos". The Journal of Environment and Development, 19:274-299.

2013. "Biological and Social Histories of the Indigenous and Protected Area Corridor of the Xingu”. Philosophical Transactions of the Royal Society B: Biological Sciences (in press).

STAHL, Peter. 1995. Archaeology in the Lowland American Tropics: Current Analytical Methods and Applications. Cambridge, New York: Cambridge University Press.

1996. "Holocene Biodiversity: an Archaeological Perspective from the Americas”. Annual Review of Anthropology, 25:105-126.

STAVER, A. Carla; ARCHIBALD, Sally \& LEVIN, Simon A. 2011. "The Global Extent and Determinants of Savanna and Forest as Alternative Biome States”. Science, 334:230-232.

STICKLER, Claudia et al. 2008. "Forest Carbon Monitoring and Landscape Modeling in Support of REDD: the Xingu River Headwaters of the SE Amazon”. Woods Hole Research Center, IPAM and UFMG Policy Brief for Poznan UNFCCC Conference of the Parties, Fourteenth Session.

TONEY, Joshua R. 2012. The Product of Labor: Pottery Technology in the Upper Xingu, Southern Amazon, Brazil, A.D. 700-1770. Doctoral dissertation, University of Florida. 
VERnOOY, Ronnie \& MCDOUGALL, Cynthia. 2003. Principles for Good Practice in Participatory Research: Reflecting on Lessons from the Field. In: Barry Pound et al. (eds.). Managing Natural Resources for Sustainable Livelihoods: Uniting Science and Participation. London: Earthscan. pp. 113-141.

WILLIS, Katherine J.; GILLSON, Lindsey \& BRNCIC, Terry M. 2004. "How 'Virgin’ Is Virgin Rainforest?” Science, 304(5669):402-403.

WILLIS, Katherine J., GILLSON, Lindsey \& KNAPP, Sandra (eds.). 2007. Philosophical Transactions of the Royal Society: B. Special Issue 362: Biodiversity Hotspots through Time: What Can the Past Tell us About the Future?

WOODS, William. I. et al. (eds.). 2009. Amazonian Dark Earths: Wim Soembrok's Vision. Springer: New York. 


\section{Resumo}

Os estudos de sustentabilidade no século XXI reconhecem amplamente que os vínculos teóricos e práticos entre ciências naturais e sociais são necessários para se entender a dinâmica de sistemas humano-naturais, especialmente na escala de séculos e milênios. A arqueologia e estudos congêneres sobre a história local indígena têm um papel crucial para entendermos a dinâmica de longo prazo de sistemas humano-naturais e a formação de paisagens culturais na Amazônia, inclusive a influência antropogênica do passado e o uso atual da terra por descendentes de populações indígenas locais. Esses estudos têm por objetivo levantar questões chave em pesquisas tropicais contemporâneas, principalmente, sobre como seres humanos precipitaram, direcionaram ou foram influenciados por mudanças ambientais ao longo do tempo em termos de respostas e resiliência frente a mudanças ecológicas, gestão sustentável de recursos naturais, além da herança indígena e direitos culturais. Além disso, esse entendimento fornece soluções alternativas "caseiras" ligadas a sistemas semi-intensivos indígenas de uso da terra, incluindo a substancial engenharia de paisagem e como funcioram e mudaram. Portanto, as estratégias indígenas de gerenciamento de recursos, enquanto modelos de uso alternativo da terra, contêm indícios vitais para o desenvolvimento sustentável e mitigação de mudanças climáticas, além de adaptação a longo prazo. Este trabalho elabora essas ideias do ponto de vista específico do Alto Xingu no sul da Amazônia brasileira, enfatizando que a questão crítica a ser posta pelos arqueólogos, depois que já estejam bem adiantadas as tarefas de escavar, mapear, rearranjar e falar sobre coisas do "passado", é a seguinte: quais são as questões sociais e éticas dessa pesquisa, especialmente em termos dos próprios povos indígenas.

Palavras-chave: Amazônia, Arqueologia, Estudos de Sustentabilidade, Herança Cultural, Povos Indígenas 


\section{Abstract}

Sustainability studies in $21^{\text {st }}$ century widely acknowledge that theoretical and practical linkages between natural and social sciences are required to understand the dynamics of coupled human-natural systems, particularly over centennial and millennial scales. Archaeology and affiliated studies on local indigenous history play a critical role in understanding the long-term dynamics of human-natural systems and the formation of cultural landscapes in Amazonia, including past anthropogenic influence and contemporary land-use by descendant local indigenous populations. Such studies aim to address key questions in contemporary tropical research regarding, notably how humans have precipitated, directed, or were influenced by environmental changes over the long-term and, in terms of responses and resiliency in the face of ecological change, sustainable management of natural resources, and indigenous heritage and cultural rights. Moreover, this understanding provides alternative "home grown" solutions, tied to sustainable semi-intensive systems of indigenous land-use, including substantial landscape engineering, and how they functioned and changed. Indigenous resource management strategies, as models of alternative land-use, thus hold vital clues to sustainable development and climate change mitigation and adaptation over the long term. This paper expands on these ideas from the specific context of the Upper Xingu, in the southern Brazilian Amazon, stressing that the critical question archaeologists must ask, after the work of digging up, mapping, shuffling and talking about things of "the past" is well underway, is this: what are the social and ethical questions of this research, particularly in terms of indigenous peoples themselves.

Keywords: Amazonia, Archaeology, Sustainability Studies, Cultural Heritage, Indigenous Peoples 